\title{
Clinical and Radiographic Efficacy of Portland Cement as Pulpotomy Material in Human Primary Molar
}

\author{
Shanta KN ${ }^{1}$, Bashar A.K.M², Hossain $\mathrm{M}^{2}$, Sheikh MAH ${ }^{4}$, Alim A ${ }^{5}$, Moral AA ${ }^{2}$ \\ ${ }^{I}$ Deptt. of Conservative Dentistry \& Endodontics, MH Samarita Medical College, Dhaka, Bangladesh \\ ${ }^{2}$ Deptt. of Conservative Dentistry \& Endodontics, BSMMU, Dhaka, Bangladesh \\ ${ }^{4}$ Deptt. of Conservative Dentistry \& Endodontic, CMH, Savar Cantt., Dhaka, Bangladesh \\ ${ }^{5}$ Deptt. of Oral and Maxillo Facial Surgery, MH Samarita Medical College, Dhaka, Bangladesh \\ e-mail:shantakamrunnahar@yahoo.com
}

\begin{abstract}
Mineral trioxide aggregates (MTA) has been considered one of the most effective pulpotomy materials as it induces the formation of dentine at a greater rate with superior structural integrity, minimal inflammation and nominal hyperplasia. Portland cement (PC), posing the principal chemical elements with similar mechanisms of action, physical properties and biocompatibility like MTA, may be considered as effective alternative for the same. So, the objective of the study was to compare the clinical and radiographic outcome of Portland cement and mineral trioxide aggregates as pulpotomy material in primary teeth. A total of 40 patients having deep carious primary tooth with mild thermal sensitivity were enrolled in this study. Pulpotomy 20 patients were treated with Portland cement and the remaining 20 patients were treated with mineral trioxide aggregates, those considered as group A and group B respectively. Then, clinical and radiological examinations were performed at 3,6 and 12 months interval to investigate the incidence of postoperative pain, swelling, dentinal bridge formation and root resorption. After a period of one year, a total of $60.0 \%$ teeth treated by Portland cement and $50.0 \%$ teeth treated by MTA group came out successfully both clinically and radiographically. All these treated teeth that came out successful remained vital having no pain clinically along with radiological evidence of dentin bridge formation and absence of internal resorption. The difference between the tested groups was not statistically significant ( $p>0.05$ ). It can be considered that Portland cement (PC) can also be used as successful pulpotomy material as an effective and economic substitute of MTA.
\end{abstract}

Keywords: Pulpotomy, Mineral trioxide aggregate, Portland cement

\section{Introduction}

Retention of pulpally involved deciduous tooth in a healthy state until the time of normal exfoliation remains to be one of the challenges for Pedodontists. Pulpotomised teeth help in maintaining arch integrity by allowing preservation of the teeth that would otherwise be destined for extraction. ${ }^{1-2}$ Concerns have been raised about the toxicity and potential carcinogenicity of the currently used pulpotomy materials, and alternatives have been proposed to maintain the partial pulp vitality. MTA showed effectiveness in vital pulp therapy procedures both in animals and human. ${ }^{3-10}$ However, the use of this much overpriced commercial dental MTA for primary teeth endodontics in a developing country like Bangladesh, is a great problem and discouraging the parents about the treatment.

Portland cement is a major bulk of MTA, differs from MTA by the absence of Bismuth ions and the presence of potassium ions. ${ }^{11-15}$ Both materials have comparable antibacterial activity and almost identical properties macroscopically, microscopically and by X-ray diffraction analysis. ${ }^{11,12,14,16}$ The main goals of using MTA and Portland cement are to induce dentin bridge formation and to maintain pulp vitality. ${ }^{17}$ So, there is strong background that the PC should be used as pulpotomy materials in human primary teeth after sufficient clinical trial. Until these 
days, there are few reports on the use of PC as medicaments in human primary teeth, but significant body of research is needed to accept $\mathrm{PC}$ as an effective and economic substitute of MTA. ${ }^{18-20}$ So, the present study was carried out to evaluate $\mathrm{PC}$ as an effective and alternative material in comparison to MTA. Taking into account, the low cost and widely availability with apparently similar properties of PC in comparison to MTA, it is reasonable to consider $\mathrm{PC}$ as an effective and economic substitute for MTA in endodontic applications. ${ }^{15,21-22}$

\section{Materials and Methods}

This quasi experimental study was conducted in the Department of Conservative Dentistry \& Endodontics, Bangabandhu Sheikh Mujib Medical University (BSMMU), Dhaka, Bangladesh. After thorough history taking, clinical and radiographic evaluation;6-9 years old patients having deep carious primary teeth with exposure of the pulp radiographically with mild thermal sensitivity but completely formed root were selected for the study. Mechanical exposure of pulp, un-restorable teeth, previously treated or restored teeth were discarded for this purpose. Purposive sampling technique was employed to select the cases. A total of 40 primary teeth were selected and divided into 2 groups: group A for Portland cement (PC) pulpotomy and group B for mineral trioxide aggregates (MTA) pulpotomy.

Each and every tooth was treated with aseptic condition, under local anesthesia with rubber dam isolation and salivary ejector. Surrounding caries and roof of pulp chamber was removed with number-4 round bur running at high-speed hand piece and copious water spray. Coronal pulps from pulp chamber were removed by using sterile excavator until the orifices of canal are seen. Finally, the pulp chamber was rinsed with normal saline and the orifices were covered with a small cotton pellet soaked in normal saline with pressure until bleeding is controlled.

Patients in group A, sterilized Portland cement were mixed with bismuth oxide (8:2) and then mixed with sterile water (3:1) into a smooth mix. Patients in group B, Pro-Root MTA (Densply), were mixed according to the manufacture's recommendations (3:1) using plastic spatula. The smooth mix of PC and MTA applied over the pulp and into the base of the prepared cavity accordingly. Then, by using a sterile cotton pellet moistened with distilled water mixed cements were condensed properly over the chamber. After the setting of the cement, the rest of the cavity was filled with Fuji-IX Glassionomer cement. Bite was checked for any high spots and 2 coats of varnish were applied over the Glass-ionomer Filling. Then, post-operative radiograph (figure 2B) was taken.

The children were recalled for clinical and radiographic evaluations after 3,6 and 12 months interval for the assessment of pain, vitality test, dentinal bridge formation and root resorption. Pain was assessed by universal VAS scale for pain and vitality teat carried out together with thermal test and EPT. Collected data were analyzed using Statistical Package for Social Science (SPSS) version 17. Statistical analyses were performed by Chi-square and Fisher's exact test to assess the difference between the clinical outcome of Group A and B; a value of $p<0.05$ was considered as statistically significant.

\section{Results}

In the present study, where success was defined as the teeth will remain vital and symptom (pain) free after pulpotomy along with radiological evidence of dentin bridge formation but no internal resorption; $60.0 \%$ teeth came out successful when pulpotomy carried out using PC than $50.0 \%$ teeth using MTA. PC showed a faster dentin bridge formation than MTA. There was no statistically significant difference $(p>0.5)$ was to be found between the two steps.

Only one tooth (5\%) became symptomatic and non vital after 6 months in MTA group and after 12 months in PC group. There was no statistical significance in respect of post operative pain and maintaining tooth vitality (table I). 
Table I: Clinical assessment of post-operative pain and pulp vitality $(n=40)$

\begin{tabular}{|c|c|c|c|c|c|c|c|c|c|}
\hline & \multicolumn{4}{|c|}{$\begin{array}{c}\text { Group A (PC) } \\
(\mathbf{n}=\mathbf{2 0})\end{array}$} & \multicolumn{4}{|c|}{$\begin{array}{c}\text { Group B (MTA) } \\
(\mathbf{n}=\mathbf{2 0})\end{array}$} & \multirow[t]{3}{*}{$\begin{array}{c}p \\
\text { Value }\end{array}$} \\
\hline & \multicolumn{2}{|c|}{ Pain status (VAS Score) } & \multicolumn{2}{|c|}{$\begin{array}{l}\text { Pulp vitality } \\
\text { status }\end{array}$} & \multicolumn{2}{|c|}{ Pain status (VAS Score) } & \multicolumn{2}{|c|}{$\begin{array}{c}\text { Pulp vitality } \\
\text { status }\end{array}$} & \\
\hline & $\mathbf{n}$ & $\%$ & $\mathbf{n}$ & $+/-$ & $\mathbf{n}$ & $\%$ & $\mathbf{n}$ & $+/-$ & \\
\hline \multicolumn{10}{|l|}{ After 3 months } \\
\hline No pain & 20 & 100 & & & 20 & 100 & & & \\
\hline Mild pain & 0 & 0 & 20 & + & 0 & 0 & 20 & + & \\
\hline Moderate pain & 0 & 0 & & & 0 & 0 & & & \\
\hline Spontaneous pain & 0 & 0 & & & 0 & 0 & & & \\
\hline \multicolumn{10}{|l|}{ After 6 months } \\
\hline No pain & 20 & 100 & & & 19 & 95 & 19 & + & \multirow{4}{*}{0.500} \\
\hline Mild pain & 0 & 0 & 20 & + & 0 & 0 & & & \\
\hline Moderate pain & 0 & 0 & & & 1 & 5 & 1 & & \\
\hline Spontaneous pain & 0 & 0 & & & 0 & 0 & 1 & - & \\
\hline \multicolumn{10}{|l|}{ After 12 months } \\
\hline No pain & 19 & 95 & 19 & + & 19 & 100 & 19 & + & \multirow{4}{*}{0.512} \\
\hline Mild pain & 0 & 0 & & & 0 & 0 & & & \\
\hline Moderate pain & 1 & 5 & 1 & & 0 & 0 & 1 & & \\
\hline Spontaneous pain & 0 & 0 & 1 & 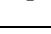 & 0 & 0 & 1 & 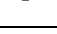 & \\
\hline
\end{tabular}

$p$ value reached from fisher exact test

Teeth treated with PC showed a faster (40\% after 3months) dentin bridge formation than those treated by MTA (25\% after 3 months). No internal resorption was evident except one in MTA group after 3 months. The difference was not statistically significant

Table II: Radiographic assessment of the groups at evaluation period $(\mathrm{n}=40)$

\begin{tabular}{|c|c|c|c|c|c|c|}
\hline \multirow{2}{*}{\multicolumn{2}{|c|}{$\begin{array}{c}\text { Radiographic } \\
\text { assessment }\end{array}$}} & \multicolumn{2}{|c|}{$\begin{array}{c}\text { Group A } \\
(\mathrm{PC}) \\
(\mathbf{n}=\mathbf{2 0})\end{array}$} & \multicolumn{2}{|c|}{$\begin{array}{c}\text { Group B } \\
\text { (MTA) } \\
(\mathbf{n}=\mathbf{2 0})\end{array}$} & \multirow[t]{2}{*}{$\begin{array}{c}p \\
\text { value }\end{array}$} \\
\hline & & $\mathbf{n}$ & $\%$ & $\mathbf{n}$ & $\%$ & \\
\hline \multicolumn{7}{|l|}{ After 3 months } \\
\hline Dentin bridge & & 8 & $\begin{array}{c}40 . \\
0\end{array}$ & 5 & 25.0 & ${ }^{\mathrm{a}} 0.311$ \\
\hline $\begin{array}{l}\text { Internal } \\
\text { resorption }\end{array}$ & root & 0 & 0.0 & 1 & 5.0 & b 0.500 \\
\hline $\begin{array}{l}\text { External } \\
\text { resorption }\end{array}$ & root & 0 & 0.0 & 0 & 0.0 & - \\
\hline \multicolumn{7}{|l|}{ After 6 months } \\
\hline Dentin bridge & & $\begin{array}{l}1 \\
2\end{array}$ & $\begin{array}{c}60 . \\
0\end{array}$ & $\begin{array}{l}1 \\
2\end{array}$ & 60.0 & ${ }^{\mathrm{a}} 1.00$ \\
\hline $\begin{array}{l}\text { Internal } \\
\text { resorption }\end{array}$ & root & 0 & 0.0 & 1 & 5.0 & b 0.500 \\
\hline $\begin{array}{l}\text { External } \\
\text { resorption }\end{array}$ & root & 0 & 0.0 & 0 & 0.0 & - \\
\hline \multicolumn{7}{|l|}{ After 12 months } \\
\hline Dentin bridge & & $\begin{array}{l}1 \\
3\end{array}$ & $\begin{array}{c}65 . \\
0\end{array}$ & $\begin{array}{l}1 \\
2\end{array}$ & 63.2 & ${ }^{\mathrm{a}} 0.732$ \\
\hline $\begin{array}{l}\text { Internal } \\
\text { resorption }\end{array}$ & root & 0 & 0.0 & 1 & 5.3 & b 0.500 \\
\hline $\begin{array}{l}\text { External } \\
\text { resorption }\end{array}$ & root & 0 & 0.0 & 0 & 0.0 & - \\
\hline
\end{tabular}

$60.0 \%$ pulpotomy was successful (no pain, vitality maintained, no resorption, and presence of dentin bridge) in PC group than $50.0 \%$ in MTA group. The difference was not statistically significant $(p>0.05)$.

Table III: Final outcome of treatment of the study population $(n=40)$

\begin{tabular}{lccccc}
\hline Site & \multicolumn{2}{c}{$\begin{array}{c}\text { Group A(PC) } \\
(\mathbf{n = 2 0})\end{array}$} & \multicolumn{2}{c}{$\begin{array}{c}\text { Group B(MTA) } \\
(\mathbf{n = 2 0})\end{array}$} & $\begin{array}{c}\boldsymbol{p} \\
\text { value }\end{array}$ \\
& $\mathbf{n}$ & $\boldsymbol{\%}$ & $\mathbf{n}$ & $\boldsymbol{\%}$ & \\
\hline Success & 12 & 60.0 & 10 & 50.0 & 0.525 \\
Failure & 8 & 40.0 & 10 & 50.0 & \\
\hline
\end{tabular}

$p$ value reached from chi square test

Clinical and radiographic evaluations were done following detail history taking of the cases. In case of Portland cement pulpotomy, deep carious lesions were identified radiographically (figure 1A) prior to operation. Furthermore, post operative X-rays were also taken (Figure 1B). Twelve (12) months follow- up periapical Xray and Radio-VisioGraphy (RVG) were also performed (figure 1C and 1D) 


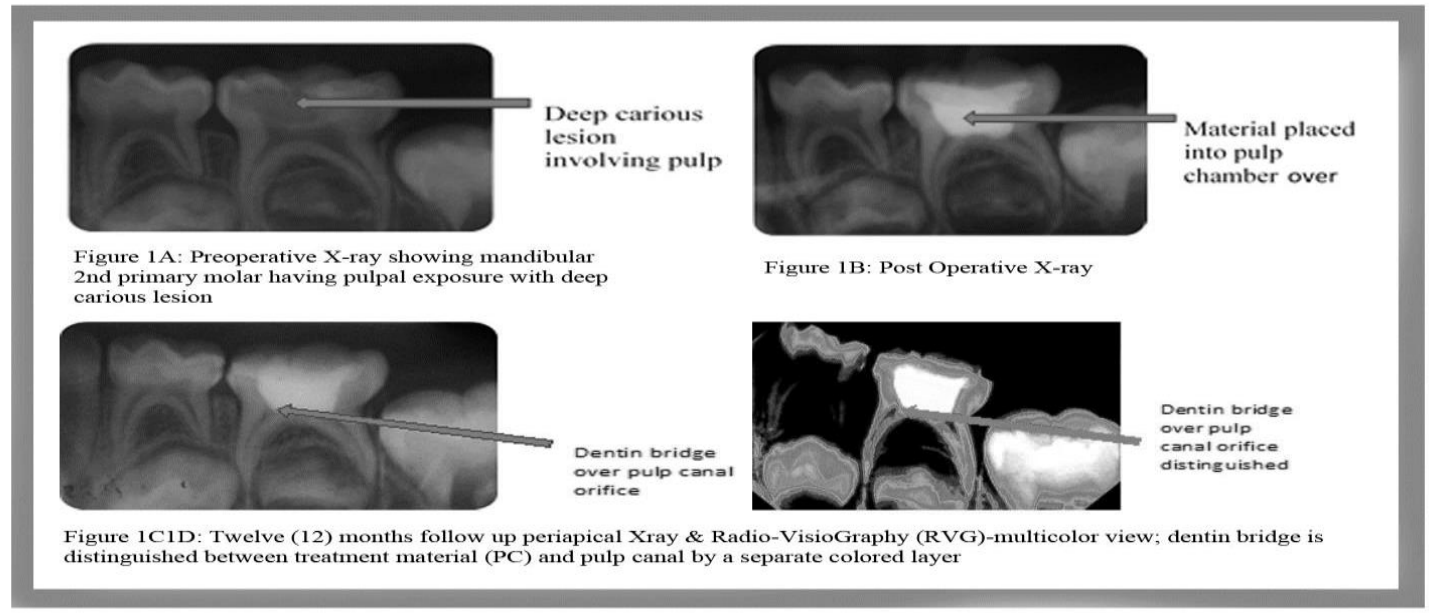

Figure 1: Sequential steps of Pulpotomy done by Portland cement

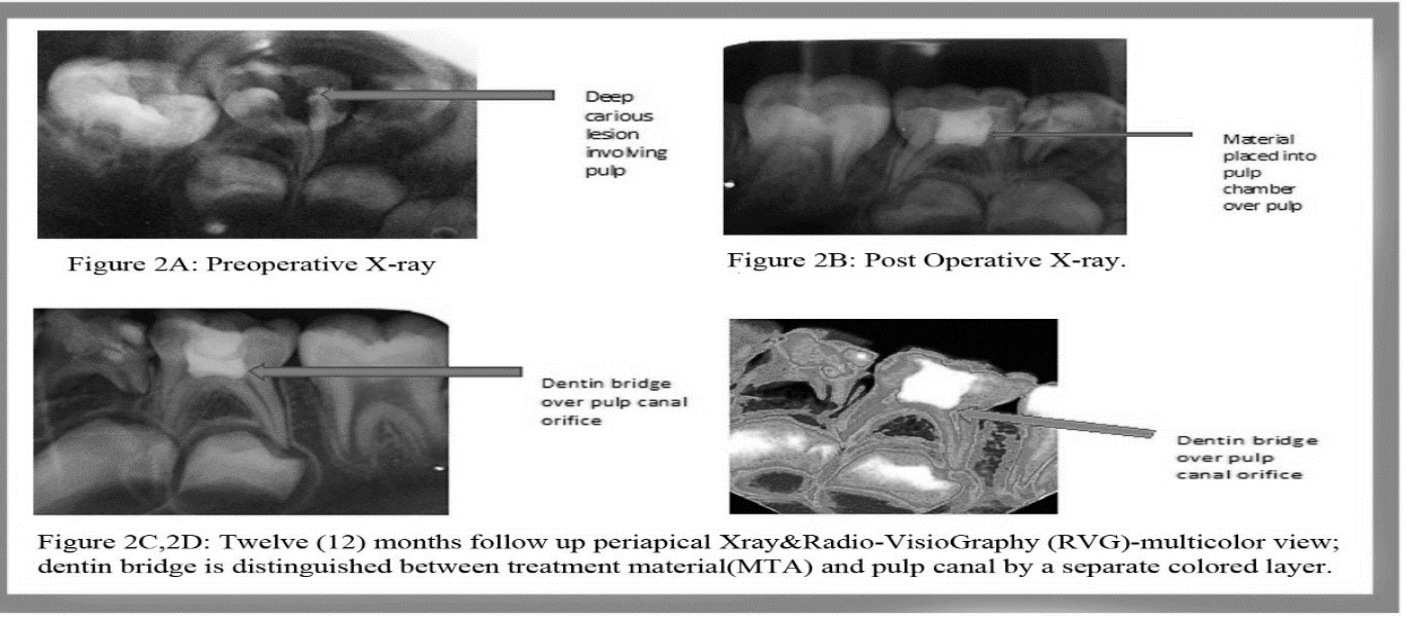

Figure 2: Sequential steps of Pulpotomy done by MTA

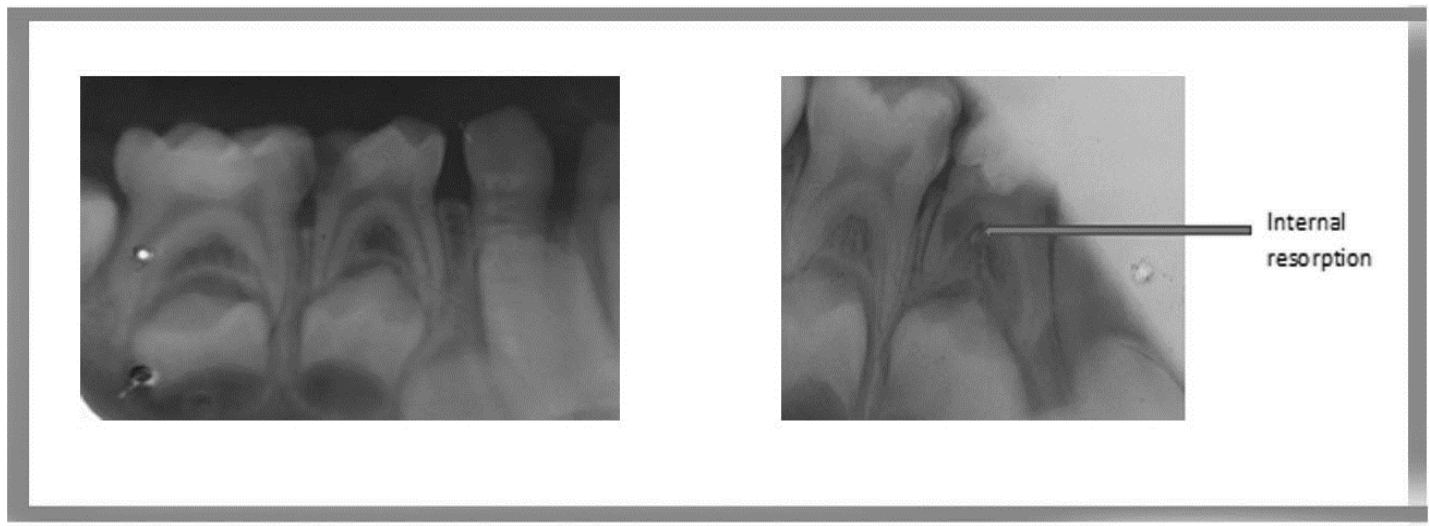

Figure 3: Resorption seen in a case of MTA treated pulpotomy

In case of MTA pulpotomy, pre and post operative X-ray were taken (figure 2A and 2B). Furthermore, Twelve (12) months follow up periapical X ray \& Radio-VisioGraphy (RVG) were also done (figure $2 \mathrm{C}$ and $2 \mathrm{D})$.

figure 3A, figure 3B: Preoperative radiograph and 3 months follow-up radiograph after pulpotomy by MTA showing internal resorption 


\section{Discussion}

In the present study, during 12 months follow up period, both the tested materials came out successful clinically and radiographically.

Sakai et al reported $100 \%$ success considering post-operative pain and maintenance of pulp vitality when teeth treated with PC and MTA. In the present study only one case (5\% of the patients) after 6 months in MTA group and after 12 months in PC group showed moderate pain and ultimately lost their vitality. ${ }^{23}$ The rest of the patients (95\% in both groups) neither complained for immediate nor long term post-operative pain, and ultimately remained vital. The pain following the treatment, might be due to pulpal inflammation without clinical signs prior the treatment because those teeth ultimately lost vitality. Furthermore, as per Maroto et al, the pain may be due to the composition of the materials too. There was no statistically significant difference between the two tested materials in respect of post-operative pain and maintenance of vitality. ${ }^{7}$

In the present study, initiation of hard tissue barrier could be recognized after 3 months in $40 \%$ cases of PC group and in 25\% cases of MTA group. The time required for hard tissue barrier initiation in the present study confirms the findings of Conti et al. who in case report stated that dentin bridge deposition could be observed after 3 months follow up immediately below PC, which was confirmed radiographically at 6 months. ${ }^{24}$ Sakai et al reported the beginning of mineralized deposition could be detected radiographically after pulpotomy in all $100 \%$ cases with PC in contrast to $57.14 \%$ at 6 months follow up and $78.6 \%$ at 12 months follow up with MTA. ${ }^{23}$ Ultimately, in the present study, dentin bridge was evident in $65 \%$ cases in PC group, in comparison to $63.2 \%$ cases in MTA group and there was no statistically significant difference. Earliest dentin bridge formation was noted at PC pulp tissue interface around 14-21 days. ${ }^{25}$ Success of PC utilization may be explained by the strong initial stimulus, able to cause an immediate response of osteo-dentin formation in an attempt to isolate the remainders of the pulp from the action of the material. ${ }^{26}$

In PC group, no tooth showed resorption throughout the total follow-up period. However, in MTA group, only one out of 20, showed internal resorption after 3 months. The result corresponded to the Agamy et al who showed internal resorption in 2 out of 33 MTA treated teeth. ${ }^{27}$ Maroto et al when studied pulpotomy with MTA, though he observed $100 \%$ success, one radiographic image resembling the initial stage of an internal resorption was detected in one of the mandibular pulp canals. ${ }^{7}$ It could be the initial phase of pulpal necrosis which would be situated in the nearest point of the MTA and could progress all along the pulp canal in the future. The internal resorption may be due to overstimulation induced by high alkalinity cause metaplasia within the pulp tissue, leading to the formation of odontoclasts and vascular change in the pulp that involves an inflammation and formation of granulation tissue, or due to the irritating effects of the medicaments present in the paste, or due to the result of undiagnosed chronic inflammation existing in the radicular pulp prior to pulpotomy. ${ }^{28-32}$

\section{Conclusion}

Portland cement and mineral trioxide aggregates could form dentine bridge and maintained pulpal vitality after pulpotomy in human primary teeth with almost similar percentage and there was no statistically significant difference. So, it can be considered that Portland Cement (PC) can also be used as successful pulpotomy material as an effective and economic substitute of MTA.

\section{References}

1. Llewelyn DR. The Pulp treatment of the primary dentition. Int J Paediatr Dent. 2000; 10: 248-52.

2. Primosch RE, Glomb TA, JerrelRG. Primary tooth pulp therapy as taught in predoctoral pediatric dental programs in the United States. Am Acad Pediatr Dent. 1997; 19:118-22.

3. American Academy of Pediatric Dentistry. Guideline on pulp therapy for primary and young permanent teeth. Pediatr Dent. 2004; 26:115-9.

4. Hewlett ER, Mount GJ. Glass ionomers in contemporary restorative dentistry - a clinical update. J Calif Dent Assoc. 2003; 31: 483-492.

5. Moretti AB, Sakai VT, Oliveira, Fornetti AP, Santos CF, Machado MA, Abdo RC. The effectiveness of mineral trioxide aggregate, calcium hydroxide and formocresol for pulpotomies in primary teeth. Int Endod J. 2008; 41: 547-55.

6. Barrieshi-Nusair KM, Qudeimat MA. A prospective clinical study of mineral trioxide aggregates for 
partial pulpotomy in cariouslym exposed permanent teeth. J Endod. 2006; 32: 731-735.

7. Maroto M, Barberia E, Vera V, Garcia-Gadoy F. Dentin bridge formation after white mineral trioxide aggregate (white MTA) pulpotomies in primary molars. Am J Dent. 2006; 19: 45-79.

8. Moretti AB, Oliveira TM, Sakai VT, Santos CF, Machado MA, Abdo RC. Mineral trioxide aggregate pulpotomy of a primary second molar in a patient with agenesis of the permanent successor. Int Endod J. 2007; 40:738-45.

9. Aeinehchi M, Dadvand S, Fayazi S, Bayat-Movahed S. Randomized controlled trial of mineral trioxide aggregate and formocresol for pulpotomy in primary molar teeth. Int Endod J. 2007; 40: 261-267.

10. Schmitt D, Lee J, Bogen G. Multifaceted use of TK/f ProRoot MTA root canal repair material. Am Acad Pediatr Dent. 2001; 23: 326-30.

11. Schwartz RS, Mauger M., Clement DJ, Walker WA III. Mineral trioxide aggregates: A new material for endodontics. J Am Dent Assoc. 1999: 130.

12. Torabinejad M, HigaRK, McKendry DJ, Pitt Ford TR. Dye leakage of four root-end filling materials: effect of blood contamination. J Endod. 1994; 20: 159-63.

13. Torabinejad M, Hong CU, Ford TRP, Kettering JD. Antibacterial effects of some root end filling materials. Journal of Endodontics. 1995; 21: 403406.

14. Stowe TJ, Sedgley CM, Stowe B, FennoJC. The effects of chlorhexidine gluconate $(0.12 \%)$ on the antimicrobial properties of tooth-colored Pro-root MTA. Journal of Endodontics. 2004: 30: 429-431.

15. Estrela C, Bammann LL, Pimenta FC, Pecora JD. Control of microorganisms in vitro by calcium hydroxide pastes. Intern Endod J. 2001; 34: 341.

16. Sipert $\mathrm{C}$, Hussne R, Nishiyama $\mathrm{C}$, Torres $\mathrm{S}$. In vitro antimicrobial activity of fill canal, sealapex, mineral trioxide aggregate, Portland cement and endorez. International Endodontic Journal. 2005; 38: 539-43.

17. Eldeniz AU. Antibacterial effect of selected root-end filling material. Journal Endod. 2006; 32: 345-349.

18. Al-Hezaimi K. Antibacterial effect of two MTA presentation against Enterococcus fecalis \& Streptococcuss anguis in vitro. Journal Endod. 2006; .32: 1053-1056.

19. Tanomaru-filho M. In vitro antimicrobial activity of endodontic sealers, MTA -based cement \& portland cement. Journal of Oral Science. 2007; 49: 41-45.
20. Asaray S, Kamrani FA. Antibacterial effect of five different root canal saeling materials. Journal of Oral Science. 2008; 50: 469-474.

21. Torabinejad M, Koh ET, McDonald F, Pitt Ford TR, Torabinejad M. Cellular response to Mineral Trioxide Aggregate. J Endod. 1998; 24: 543-7.

22. Jabbarifar SE, Khademi AA, Ghasemi D. Success rate of formocresolpulpotomy versus mineral trioxide aggregate in human primary molar tooth. J Res Med Sci. 2004; 6: 55-58.

23. Sakai VT, Moretti AB, Oliveira TM, Fornetti AP, Santos CF, Machado MA et al. Pulpotomy of human primary molars with MTA and Portland cement: a randomised controlled trial. Br Dent J. 2009; 207: E5.

24. Conti TR, Sakai VT, FornettiAPC, Moretti ABS, Oliveira TM, LourençoNeto $\mathrm{N}$ et al. Pulpotomies with Portland cement in human primary molars. Journal of Applied Oral Science. 2009; 17: 66-9.

25. Barbosa AV, Sampaio GC, Gomes FA, de Oliveira DP, de Albuquerque DS, Sobral AP. Short-term analysis of human dental pulps after direct capping with portland cement. Open Dent J. 2009; 3:31-5.

26. Browne RM. Animal tests for biocompatibility of dental materials relevance, advantages and limitations. J Dent. 1994; 22: 21-4.

27. Agamy HA, Bakery NS, Mounir MM, Avery DR. Comparison of MTA and FC as pulp capping agents in pulpotomized primary teeth. Podiatry Dent. 2004 ;302-9.

28. Magnusson BO. Pulpotomy in primary molars: Long-term clinical and histological evaluation. Int Dent J. 1980; 13: 143-55.

29. Faraco IM, Holland R. Response of pulp of dogs to capping with mineral trioxide aggregate or calcium hydroxide cement. Dent Traumatol. 2001; 17:163-6.

30. Smith NL, Seale NS, Nunn ME. Ferric sulfate pulpotomy in primary molars: A retrospective study. Pediatr Dent. 2000; 22: 192-9.

31. Hicks JM, Barr ES, Flaitz CM. Formocresolpulpotomies in primary molars: A radiographic study in a pediatric dentistry practice. J Pedod. 1986; 10: 331-9.

32. Sonmez D, Sari S, Cetinbas T. A comparison of four pulpotomy techniques in primary molars: A long term follow-up. J Endod. 2008; 34: 950-5. 